IRA-International Journal of Management \& Social Sciences

ISSN 2455-2267; Vol.04, Issue 02 (2016)

Pg. no. 417-422

Institute of Research Advances

http://research-advances.org/index.php/RAJMSS

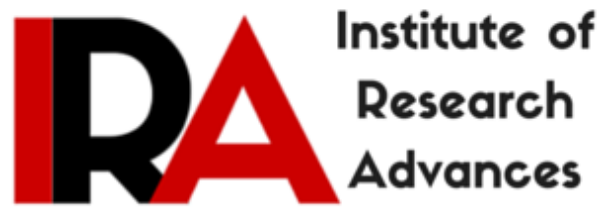

\title{
Effectiveness of Persuasive Media on Risk Oriented Habits
}

\author{
${ }^{1}$ Uma Soni (M.Sc. Student) \\ Department of EECM, CCSHAU, \\ Hisar, Haryana, India. \\ 2 Beena Yadav \\ Associate Director, Directorate of Research CCSHAU, \\ Hisar, Haryana, India.
}

Type of Review: Peer Reviewed.

DOI: http://dx.doi.org/10.21013/jmss.v4.n2.p10

\section{How to cite this paper:}

Soni, U., \& Yadav, B. (2016). Effectiveness of Persuasive Media on Risk Oriented Habits. IRA-International Journal of Management \& Social Sciences (ISSN 2455-2267), 4(2), 417-422. doi:http://dx.doi.org/10.21013/jmss.v4.n2.p10

(C) Institute of Research Advances

\section{(cc) EY-NO}

This work is licensed under a Creative Commons Attribution-Non Commercial 4.0 International License subject to proper citation to the publication source of the work.

Disclaimer: The scholarly papers as reviewed and published by the Institute of Research Advances (IRA) are the views and opinions of their respective authors and are not the views or opinions of the IRA. The IRA disclaims of any harm or loss caused due to the published content to any party. 


\begin{abstract}
The study was conducted in Haryana and Rajasthan states covering a sample of 200 respondents (100 male and female each) from two villages and two slum areas of each state. Print (VCD) as well as electronic media (Booklet) was developed, standardized and exposed to the selected respondents on five risk oriented habits viz; use of tobacco; drinking alcohol; and poor environmental, eating and personal habits. There was significant gain in knowledge about health hazards due to all the five risk oriented habits. The gain in knowledge about persuasive messages on consumption of tobacco was highest followed by use of alcohol, poor personal, environmental and eating habits. Direct impact of persuasive messages was perceived in term of ease in understanding and following which would help the respondents in dealing with the related problems immediately. Indirect impact of intervention programme was perceived in terms of changes in the habits in the coming time as it has improved consciousness, confidence and motivation to deal with the risk oriented habits.
\end{abstract}

Key words: Risk Oriented Habits, media, knowledge, impact, parameters

\title{
Introduction
}

Health risk communication has become the subject of scientific research within the last decade only. What the general public thinks and perceive about health risks is of paramount importance. People in general have the tendency to either overestimate or underestimate certain risks. In lifestyle related risk oriented habits such as smoking, alcohol and sexual behaviour, public concern regarding health risks is sometimes much less than the experts feel to be appropriate as risk is controlled by personal efforts. For example most smokers can think of some distant relative who rolled his own cigarettes, smoked heavily and yet lived to the age of 90 while few others might have firsthand experience of people suffering from smoking-related disease. Also in a survey of mass media reports in the United States on emerging and chronic health hazards like severe acute respiratory syndrome (SARS), bioterrorism, West Nile Fever, AIDS, smoking and physical inactivity were counted for the year 2003. SARS and bioterrorism killed less than a dozen people in 2003, but together generated over 100,000 media reports, far more than those covering smoking and physical inactivity, which kill nearly a million Americans (Bomlitz and Brezis, 2008). So there is an increasing need for health risk communication in present era as it has been estimated that about $36.0 \%$ of men population smoke compared to $8.0 \%$ of women, globally and claiming about 4.9 million lives annually (Verma, 2008). Alcohol causes nearly $4.0 \%$ of deaths worldwide, more than AIDS, tuberculosis or violence (WHO, 2010). Pollution of freshwater is a problem for about half of the world's population. Each year there are about 250 million cases of water-related diseases, with roughly 5 to 10 million deaths (Ranjan, 2011). Malnutrition kills 5 million children every year killing one child every 6 seconds, 57 million children are underweight and more than $50.0 \%$ of deaths in $0-4$ years are associated with malnutrition (Rekha, 2010).

India has come a long way being on the verge of putting gory pictures on cigarette packs to, inscribing statutory warning "Cigarette Smoking is injurious to Health"(from 1975). On 2nd November, 2001, the Supreme Court passed an order that smoking in public places is a punishable offence subsequently passing an act in 2003 according to which advertisement on cigarettes and tobacco products were prohibited. The fact is that there is widespread ignorance and majority of the population is not aware of these legal sanctions. The present study was thus designed to address the specific objective of development and effectiveness assessment of persuasive media on risk oriented habits

\section{Methodology}

The present study was carried out in Haryana and Rajasthan states. The two district headquarters namely Hisar and Jodhpur from Haryana and Rajasthan, respectively were selected purposively on the basis of proximity and convenience of the researcher. One village in proximity of five to seven kilometers of each of the selected district headquarter was selected at random. Consequently two villages namely 
Patan from Hisar and Jhanwar from Jodhpur were selected for the purpose. Similarly one slum area from the selected district headquarters i.e. labour colony from Hisar and Nat basty from Jodhpur were selected at random. Total sample of 200 i.e. 100 each with rural and slum background covering 100 men and 100 women were included for the purpose of the study.

Risk oriented health habits in present study were operationalized as habits or action taken by an individual which causes a disease or danger to health resulting from exposure to a lifestyle influence. The risk oriented health habits included in the study were use of tobacco, drinking alcohol, poor environmental, eating and personal habits based on experts' judgment.

The data were collected into three phases i.e. denvelopment, intervention and assessment.

During development phase, media was developed and standardized in the form of print (module) as well as electronic form (VCD) on five risk oriented health habits. The media package contained information on the causes and effects of risk oriented habits along with perceptual aspects in the form of photographs and hard facts as knowledge alone can't help individuals to change their mind set. The media was developed in Hindi as well as English. The intervention phase included rapport and environment building with the respondents. Thorough discussion was held with the respondents before, during and after media exposure Lectures were delivered by the researcher at the initial stage of intervention programme. The delivery of lecture leading to discussion constituted important component of intervention phase. In continuation the electronic media package was introduced to the respondents.

Under third phase, impact assessment of the media containing persuasive messages was measured in terms of three aspects viz. changes in the behavioral components, the type of impact the developed media was able to create on the respondents and effectiveness of media in terms of selected parameters. Paired' $t$ ' test was used to know the differential gain in knowledge and change in opinion of the respondents about selected risk oriented health habits..

\section{Results}

Changes in knowledge about hazards of risk oriented habits: The results of the study revealed that knowledge gain about health hazards due to use of all the risk oriented habits i.e. use of tobacco, drinking alcohol, environmental habits, poor eating habits and personal habits habits was found significant. As the knowledge statements for each of the selected habit were 10, therefore there was no need to calculate pre, post or gain in knowledge in percentage. The knowledge data based on mean scores are given in Table 1.The gain in knowledge about persuasive messages on consumption of tobacco was highest (6.68) followed by gain in knowledge about message on use of alcohol (5.64), personal habits (5.45), environmental habits (5.16) and eating habits (5.08).It can therefore be concluded that the persuasive message exposure related to all the five selected risk oriented health habits was successful in changing the knowledge of respondents significantly.

Table 1: Changes in knowledge about hazards of risk oriented habits

\begin{tabular}{|l|l|l|l|l|}
\hline $\begin{array}{l}\text { Habit } \\
\text { (Maximum score 10 } \\
\text { for each) }\end{array}$ & $\begin{array}{l}\text { Pre exposure } \\
\text { (mean) }\end{array}$ & $\begin{array}{l}\text { Post exposure } \\
\text { (mean) }\end{array}$ & $\begin{array}{l}\text { Gain in } \\
\text { knowledge }\end{array}$ & $\begin{array}{l}\text { 't' } \\
\text { value }\end{array}$ \\
\hline Use of tobacco & 1.43 & 8.11 & 6.68 & $31.31^{*}$ \\
\hline Use of alcohol & 2.52 & 8.16 & 5.64 & $25.13^{*}$ \\
\hline $\begin{array}{l}\text { Poor environmental } \\
\text { habits }\end{array}$ & 1.53 & 6.69 & 5.16 & $22.28^{*}$ \\
\hline
\end{tabular}




\begin{tabular}{|l|l|l|l|l|}
\hline Poor eating habits & 1.93 & 7.01 & 5.08 & $20.49^{*}$ \\
\hline Poor personal habits & 2.67 & 8.13 & 5.45 & $23.05^{*}$ \\
\hline
\end{tabular}

$*$ significant at $5 \%$ level of significance

\section{Perceived impact of the persuasive messages}

Two types of impact i.e. direct /quantitative impact and indirect/ qualitative impact of exposing persuasive media to the respondents were as assessed. Table 2 indicates the type of impact perceived by respondents after. Direct impact was perceived in term of five ways and it was found that more than 80.0 $\%$ of the respondents perceived that intervention on persuasive messages was easy to understand and follow $(84.0 \%)$ and will also help the respondents in dealing with the risk oriented habits immediately (83\%). The intervention through media exposure was perceived to help in improving the knowledge, opinion and perception about risk oriented habits $(80.0 \%)$. Majority of the respondents also perceived that such messages will also help them to dealing with the risk oriented habits in coming time (76.0\%) and $49.0 \%$ of the respondents indicated their will to change the risk oriented habit from the day of intervention itself.

Maximum number of respondents perceived the indirect impact of intervention programme in terms of change in their habits in the coming time (87.5) followed by the respondents who were of the view that though the specific impact of intervention programme is difficult to spell out, however, it is going to impact their lives (79.5) certainly. Improved consciousness, confidence and motivation to change the habits was reported by $58.0 \%$ of respondents. Two types of indirect impact i.e. improvement in health of the family members and monitory benefits were perceived by comparatively less number of respondents (26.5\% and $24.5 \%$, respectively) .

Table 2: Perceived impact of the persuasive messages $(\mathbf{n}=\mathbf{2 0 0})$

\begin{tabular}{|l|l|l|l|}
\hline \multicolumn{1}{|c|}{ Impact } & \multicolumn{1}{|c|}{ Impact statement/ Item } & Number & Percent \\
\hline $\begin{array}{l}\text { Direct/quantitati } \\
\text { ve impact }\end{array}$ & $\begin{array}{l}\text { Persuasive messages were easy to understand and } \\
\text { follow. }\end{array}$ & 168 & 84.0 \\
\cline { 2 - 4 } & $\begin{array}{l}\text { The messages will help me in dealing with the risk } \\
\text { oriented habits immediately }\end{array}$ & 166 & 83.0 \\
\cline { 2 - 4 } & $\begin{array}{l}\text { The intervention has improved my knowledge, } \\
\text { opinion and perception about risk oriented health } \\
\text { habits }\end{array}$ & 160 & 80.0 \\
\cline { 2 - 4 } & $\begin{array}{l}\text { It will help me in dealing with the risk oriented habits } \\
\text { in coming time. }\end{array}$ & 152 & 76.0 \\
\cline { 2 - 4 } $\begin{array}{l}\text { Indirect/qualitati } \\
\text { ve impact }\end{array}$ & It will help to improve my habits in the coming time. & 175 & 87.5 \\
\cline { 2 - 4 } & $\begin{array}{l}\text { Certainly there will be impact of the persuasive } \\
\text { messages, but is difficult to make out now. }\end{array}$ & 159 & 79.5 \\
\cline { 2 - 4 } & $\begin{array}{l}\text { It has improved my consciousness, concern, } \\
\text { confidence, vision and motivation to change my } \\
\text { habits. }\end{array}$ & 116 & 58.0 \\
\cline { 2 - 4 } & It will help in improving the health of whole family. & 53 & 26.5 \\
\cline { 2 - 4 } & It will lead to monitory benefits & 49 & 24.5 \\
\hline
\end{tabular}

\section{Effectiveness of persuasive media in terms of selected parameter}

The inventory to measure the effectiveness of module as perceived by respondents containing 10 parameters of effectiveness was developed. The results are shown in Table 3 indicating which parameter 
of media was perceived as most/ least effective by the respondents. Audibility of media with mean score of 2.43 was perceived as maximum by majority of the respondents followed by visual appeal (2.22), consistency of speed (2.21), content presentation (2.12), comprehension of the content (2.10) and sequence of the content (2.11).These seven parameters were perceived between effective to most effective. Organization of the content (1.99), language (1.97) and readability (1.86) of persuasive media were perceived between least effective to effective.

Table 3: Effectiveness of persuasive media in terms of selected parameter $(n=200)$

\begin{tabular}{|c|c|c|c|c|c|c|c|}
\hline \multirow[b]{2}{*}{$\begin{array}{l}\text { Sr. } \\
\text { No. }\end{array}$} & \multirow[b]{2}{*}{ Parameters } & \multicolumn{3}{|c|}{ Effectiveness } & \multirow[b]{2}{*}{$\begin{array}{l}\text { Total } \\
\text { score }\end{array}$} & \multirow[b]{2}{*}{ WMS } & \multirow[b]{2}{*}{ Rank } \\
\hline & & $\begin{array}{c}\text { Most effective } \\
\text { (3) }\end{array}$ & $\begin{array}{c}\text { Effective } \\
\text { (2) }\end{array}$ & \begin{tabular}{|c|} 
Least effective \\
(1)
\end{tabular} & & & \\
\hline 1. & Content presentation & $62(186)$ & $100(200)$ & $38(38)$ & 424 & 2.12 & IV \\
\hline 2. & Visual appeal & $68(204)$ & $109(218)$ & $23(23)$ & 445 & 2.22 & II \\
\hline 3. & Audibility & $117(351)$ & $52(104)$ & $31(31)$ & 486 & 2.43 & $\mathrm{I}$ \\
\hline 4. & Readability & $50(150)$ & $72(144)$ & $78(78)$ & 372 & 1.86 & $X$ \\
\hline 5. & $\begin{array}{l}\text { Organization of the } \\
\text { content }\end{array}$ & 53 (159) & $92(184)$ & $55(55)$ & 398 & 1.99 & VIII \\
\hline 6. & Sequence of the content & $76(228)$ & $71(142)$ & $53(53)$ & 423 & 2.11 & VII \\
\hline 7. & Relevance of the content & $79(237)$ & $69(138)$ & $52(52)$ & 427 & 2.13 & VI \\
\hline 8. & Consistency of the speed & $89(267)$ & $64(128)$ & $47(47)$ & 442 & 2.21 & III \\
\hline 9. & Language & $41(123)$ & $112(224)$ & $47(47)$ & 394 & 1.97 & IX \\
\hline 10. & $\begin{array}{l}\text { Comprehension of the } \\
\text { content }\end{array}$ & 63 (189) & 94 (188) & $43(43)$ & 420 & 2.10 & V \\
\hline \multicolumn{5}{|c|}{ Total score $=$} & 4231 & & \\
\hline
\end{tabular}

Figures in parenthesis indicate weighted score

\section{Discussion and Conclusion}

The results of the study revealed that there was significant difference in knowledge about health hazards or consequences due to selected risk oriented health habits i.e. use of tobacco, drinking alcohol, environmental habits, poor eating habits and personal habits showing the effectiveness of the developed media. The media exposure containing persuasive messages on risk oriented habits impacted the respondent directly as well as indirectly. The selected media covered persuasive messages on risk oriented habits in terms of hard facts and images may be used not only by the health department but also by the persons like extension workers, government functionaries, NGOs, rehabilitation centers, etc. who are directly or indirectly associated with health promotion. The bilingual quality of media (English as well as Hindi) widens its scope of utilization by professionals as well as local/ rural people.

\section{BIBLIOGRAPHY}

- Bomlitz, L. and Brezis, M. 2008. Misrepresentation of health risks by mass media.Public-Health. 30(2): 202-204

- Ranjan S. 2011. Facts about water pollution.URL: http://www.buzzle.com/articles/facts-aboutwater-pollution.html

- Rekha, W. 2010. Mother and Child Nutrition. URL: http://motherchildnutrition.org/

- Verma, O.S. 2008.Smoking is injurious to health. J. Extension system, 24:111-122. 
- WHO. 2010. Chandigarh adults consume 136 bottles of alcohol annually. News India, Jan. URL:http://www.indianexpress.com/ie/daily/20000626/ina26001.html 